\title{
Diel changes in bacterial biomass and growth rates in coastal environments, determined by means of thymidine incorporation into DNA, frequency of dividing cells (FDC), and microautoradiography
}

\author{
Bo Riemann ${ }^{1}$, Per Nielsen ${ }^{1}$, Mette Jeppesen ${ }^{1}$, Birgitte Marcussen ${ }^{1}$ and \\ Jed A. Fuhrman ${ }^{2}$ \\ ${ }^{1}$ Freshwater Biological Laboratory, University of Copenhagen, Helsingorsgade 51, DK-3400 Hillerød, Denmark \\ ${ }^{2}$ Marine Sciences Research Center, State University of New York at Stony Brook, Long Island, New York 11794, USA
}

\begin{abstract}
During 4 diel cycles in a Danish coastal environment, bacterial growth rates were estimated by several methods. ${ }^{3} \mathrm{H}$-thymidine incorporation into DNA gave results of the same order of magnitude as data obtained from frequency of dividing cells (FDC). In contrast to minor diel changes in cell numbers and bacterial secondary production, marked diel changes were observed in the percentage of active bacteria determined from microautoradiography using ${ }^{3} \mathrm{H}$-thymidine. Between 20 and $80 \%$ of the bacteria were active. Increases in percent activity were frequently but not always found in the morning. Attempts to estimate specific activity of thymidine nucleotide pools by isotope dilution procedure suggested that there was less intracellular dilution than expected from literature data; however, it seemed to be an underestimate and results were often difficult to evaluate. Results from biomass changes sometimes revealed appreciably higher production rates than those obtained from thymidine incorporation, whether or not the thymidine data were separately adjusted for presumed isotope dilution. Based on the assumption that all dividing bacteria were active, bacterial biomass and FDC were corrected according to the percent active bacteria determined from autoradiography. Corrected bacterial production rates were on average $28 \%$ (range 4 to $169 \%$ ) higher than those obtained from standard FDC procedure.
\end{abstract}

\section{INTRODUCTION}

During the past $5 \mathrm{yr}$, several new techniques have been developed to determine growth rates of bacterial assemblages in natural environments. Special attention has been paid to incorporation of nucleic acid bases and nucleosides into DNA (Fuhrman and Azam, 1980, 1982; Moriarty and Pollard, 1981) and RNA (Karl, $1979,1982),{ }^{35} \mathrm{~S}^{-} \mathrm{SO}_{4}$ incorporation into protein (Jordan and Likens, 1980; Cuhel et al., 1981) and frequency of dividing cells (Hagström et al., 1979).

At present, few comparisons have been made of results obtained from these methods. Christian et al. (1982) compared ${ }^{3} \mathrm{H}$-adenine incorporation into RNA with other methods including FDC and found that FDC

Contribution No. 413 from the Freshwater Biological I ihoratory often gave lower values. A strong correlation was reported between results obtained from FDC and thymidine incorporation into DNA (Newell and Fallon, 1982); however, FDC estimates were always between 2 and 7 times the thymidine calculated production. A similar conclusion was made by Riemann and Søndergaard (1984), who found lower results from thymidine incorporation compared to results obtained with ${ }^{14} \mathrm{CO}_{2}$ dark uptake procedures and FDC. Bell et al. (1983) compared thymidine incorporation with dark ${ }^{14} \mathrm{CO}_{2}$ uptake and found that the 2 methods agreed only when bacterial activity was high.

Each method is based on a considerable number of assumptions and illustrates different aspects of growth. Concerning FDC and thymidine techniques, assumptions have been listed and discussed by Larsson and Hagström (1982) and Fuhrman and Azam (1982), respectively One important assumption in the FDC 
technique is that calculation of growth rate assumes that all cells are metabolically active. Presence of metabolically inactive cells would underestimate the FDC percentage for the active fraction of the population and cause an error in the calculation of production.

In order to estimate bacterial growth rates from incorporation of ${ }^{3} \mathrm{H}$-thymidine into DNA, some auxilliary measurements are needed including an estimate of the extent to which extracellulat pools and de novo synthesis of thymidine nucleotides dilute the added radioactively labeled thymidine before it is incorporated into DNA. Fuhrman and Azam (1982), working off Southern California, used a series of individual experiments to make these measurements and also verified the accuracy of their production estimates by an independent means. They found that ${ }^{3} \mathrm{H}$-thymidine added at $5 \mathrm{nM}$ concentrations was diluted about 5-fold before being incorporated into DNA. Moriarty and Pollard (1981) and Moriarty (1984a, b) describe a different approach for estimating the specific activity of DNA precursors which has demonstrated little or no isotope dilution in Australian waters, though these results have not been verified by an independent means.

In this study, we compared the 2 ways of calculating production from ${ }^{3} \mathrm{H}$-thymidine incorporation with results from FDC. We also estimated metabolically active bacteria by means of microautoradiography and corrected the FDC-predicted growth rates for the presence of metabolically inactive cells during 4 diel studies in a coastal marine environment.

\section{MATERLALS AND METHODS}

Surface water samples were taken from the Limfjord off the Rønbjerg Marine Station in the northern part of Denmark. The Limfjord connects the North Sea with the Kattegat (Fig. 1); at the sampling station, the Limfjord is about $15 \mathrm{~km}$ wide. Salinity fluctuates around $27 \%$ S.

During 4 diel studies (14 to 16 Sep, and 12 to 14 Oct. 1982), water was sampled between 8 and 9 a.m. using plastic buckets. About $200 \mathrm{l}$ were transported to the harbour in a plastic container, distributed into clear 5 l glass bottles and incubated just below the surface in the harbour. Sampling from the 51 glass bottles were performed every 4 to $5 \mathrm{~h}$ during $48 \mathrm{~h}$ (14 to $16 \mathrm{Sep}$.). From 12 to 14 October, the water was replaced in the 51 bottles after $24 \mathrm{~h}$.

Two ${ }^{3} \mathrm{H}$-thymidine methods were applied:

(1) Samples (80 mi in clear Jena bottles) were incubated in situ with $12.5 \mathrm{nM}$ (methyl- ${ }^{3} \mathrm{H}$ )-thymidine (20 $\mathrm{Ci} / \mathrm{mmol}$, New England Nuclear) for 60 min (Fuhrman and Azam, 1980). Acid and base hydrolysis was used for extraction of specific macromolecules as described by Fuhrman and Azam (1982), except that addition of carrier DNA was omitted (pilot experiments showed the carrier slowed filtration but did not affect recovегу). All blanks were prepared from formalin-fixed samples ( $1 \%$ final concentration). Duplicates were prepared for all 3 macromolecular fractions. The rate of thymidine incorporation into DNA was converted into bacterial production. by assuming that $2.1 \times 10^{18}$ cells

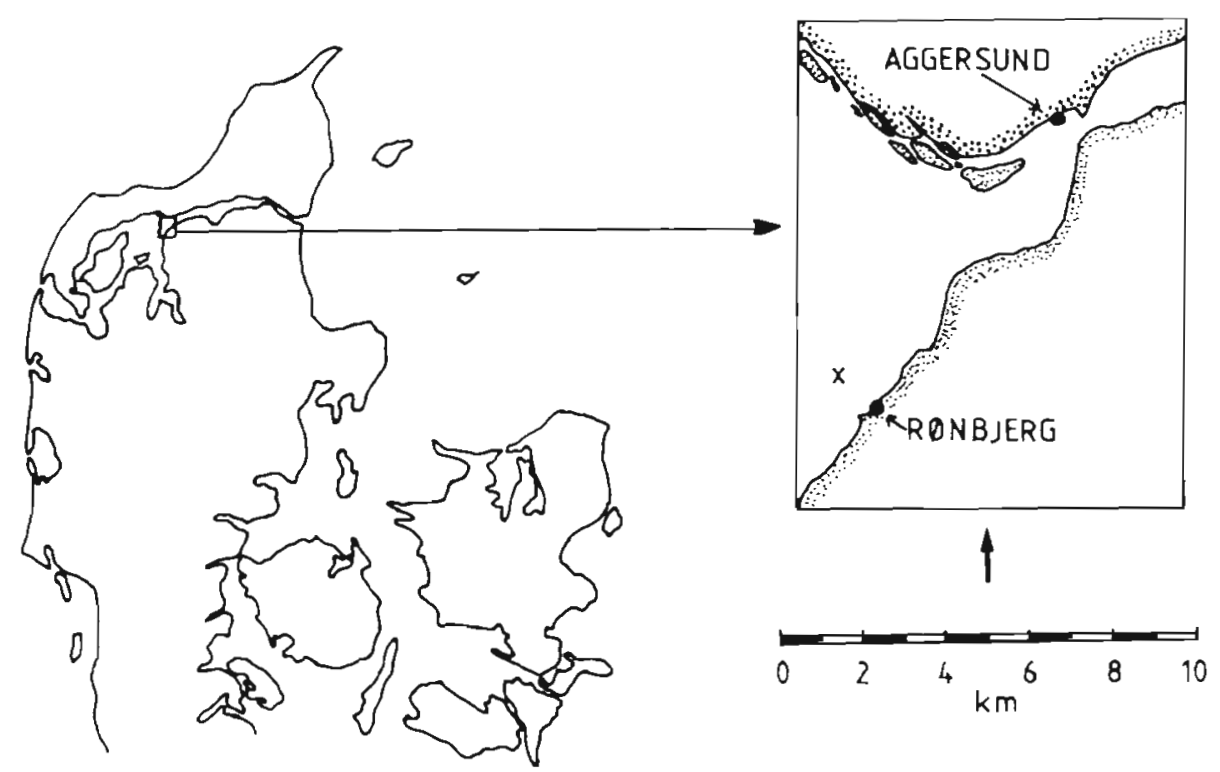

Fig. 1 Map of Limfjord area. x: sampling station 
were produced per mol thymidine incorporated (Fuhrman and Azam, 1982).

(2) Samples ( $80 \mathrm{ml}$ in clear Jena bottles) were incubated with $3.13 \mathrm{nM}$ (methyl- ${ }^{3} \mathrm{H}$ )-thymidine as well as with unlabeled thymidine concentrations $(0.00,3.13$, 6.25, 12.50 and 37.50 nM) (Moriarty and Pollard, 1981; Riemann et al., 1982). After incubating all samples for 60 min, specific macromolecules were extracted as described above. Plots were made of the reciprocal of the amount of ${ }^{3} \mathrm{H}$ incorporated into DNA fractions against the concentration of unlabeled thymidine added (Moriarty and Pollard, 1981). The isotope dilution factor was calculated according to the formula:

$$
\frac{\text { dpm } \times \text { moles }}{2.2 \times 10^{12} \times \mathrm{Ci}}
$$

where (dpm) obtained from the intercept on the ordinate; (moles) obtained from the negative intercept on the abscissa; $(\mathrm{Ci})={ }^{3} \mathrm{H}$-thymidine added. Number of cells produced per unit of time and volume were then calculated by multiplying the isotope dilution factor with $5 \times 10^{17}$ cells produced per mole thymidine incorporated. Five isotope dilution experiments were carried out in $3 \mu \mathrm{m}$ filtered seawater (see below: 1 on 15 Sep.; 4 during 14 to 16 Oct.).

For microautoradiographic determination of thymidine active bacteria, $20 \mathrm{ml}$ water samples were incubated in situ with $12.5 \mathrm{nM}{ }^{3} \mathrm{H}$-thymidine $(20 \mathrm{Ci} /$ mmol, New England Nuclear) for $3 \mathrm{~h}$ in clear Jena bottles. Controls were fixed with borate-buffered formalin to $1 \%$ final concentration. Autoradiographic preparations were made as described by Meyer-Reil (1978) with minor changes (Marcussen at al,, 1984). Microscopic examination was carried out with a Zeiss Photomicroscope II, objective Neofluar $\times 100$, ocular $\times 10$, and optivar $\times 1.6$, giving a total magnification of $\times 1,600$. Thirty randomly chosen fields were counted, each covering $6,000 \mu^{2}$. An active cell was characterized by one or several associated silver grains. The net number of active bacteria was obtained by subtracting corresponding blank values. Mean blank values were $30 \%(\mathrm{SD} 4 \%, \mathrm{n}=13)$ of sample values. These rather high control values resulted from (1) the counting procedure, where both single grains as well as clusters were counted; (2) the rather few active bacteria per counting field (15 to 20). The percentage of active cells was computed, using the total number of bacteria enumerated from separate filters.

Enumeration of bacteria followed Hobbie et al. (1977). Counting was carried out with a Zeiss epifluorescence microscope fitted with objective Neofluar $\times 100$ and oculars $\times 12.5$. Twenty randomly chosen fields, each containing about 30 cells, were counted Cell volumes of 120 cells filter $^{-1}$ were measured from enlarged black and white photographs (Fuhrman,
1981). Cell volume was converted to carbon biomass

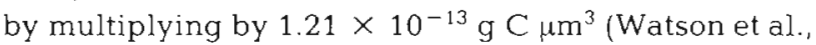
1977). Frequency of dividing cells (FDC) was counted according to Hagström et al. (1979). Specific growth rate was estimated according to Riemann (1983). A minimum of 20 dividing cells filter ${ }^{-1}$ were counted.

Production rates were also calculated from increases in bacterial biomass determined from increase in cell numbers and mean cell volumes in seawater that was incubated in situ for $10 \mathrm{~h}$. The water was gravityfiltered through $3.0 \mu \mathrm{m}$ pore-size Unipore filters before incubation. Duplicate filters for epifluorescence counts were prepared at the start of the experiment and after 5 and $10 \mathrm{~h}$. Mean volume was determined as described above. ${ }^{3} \mathrm{H}$-thymidine incorporation into DNA was also made from the $3 \mu \mathrm{m}$ filtered seawater. Both our standard procedure as well as the isotope dilution procedure were applied.

\section{RESULTS}

The number of bacteria increased from noon to midnight and decreased from midnight to noon for $2 \mathrm{~d}$ in September (Fig. 2). Throughout the 48 h, numbers decreased from $1.03 \times 10^{6} \mathrm{ml}^{-1}$ at 0900 on $14 \mathrm{Sep}$ tember to $0.70 \times 10^{6} \mathrm{ml}^{-1}$ at 0500 on 16 September. Except for a sudden peak at 1300 on 14 September, the mean volume was almost constant during the first $24 \mathrm{~h}$, then slowly increased to a maximum of $0.146 \mu \mathrm{m}^{3}$ at 0500 on 16 September. Minimum values were around $0.020 \mu^{3}$.

Active bacteria, presented as a percentage of the total number of bacteria, varied from $20 \%$ at 0900 on 14 September to $80 \%$ at 0500 on 16 September

Frequency of dividing cells (FDC) fluctuated irregularly, but increased slowly throughout the $48 \mathrm{~h}$. Maximum values between 4.5 and $5.9 \%$ were recorded at the end of the $48 \mathrm{~h}$.

Bacterial secondary production was estimated from both ${ }^{3} \mathrm{H}$-thymidine incorporation into DNA and FDC. Diel changes were similar for the 2 methods. Values from the FDC technique were slightly lower than those observed from the thymidine procedure.

In the 2 separate back-to-back diel studies from 12 to 14 October, the number of bacteria increased slowly during 12 to 13 October from $2.1 \times 10^{6}$ to $3.2 \times$ $10^{6} \mathrm{ml}^{-1}$ (Fig. 3); except for a small peak they remained constant during 13 to 14 October Mean volume fluctuated irregularly with peaks at 1300 and 0400 (12 to 13 Oct) and decreased from $0.115 \mu \mathrm{m}^{3}$ at 0900 (13 Oct) to 0.015 to $0.020 \mu \mathrm{m}^{3}$ between 2400 and 1000 on 14 October.

The percentage of active bacteria detected by autoradiography with ${ }^{3} \mathrm{H}$-thymidine was generally lower in 


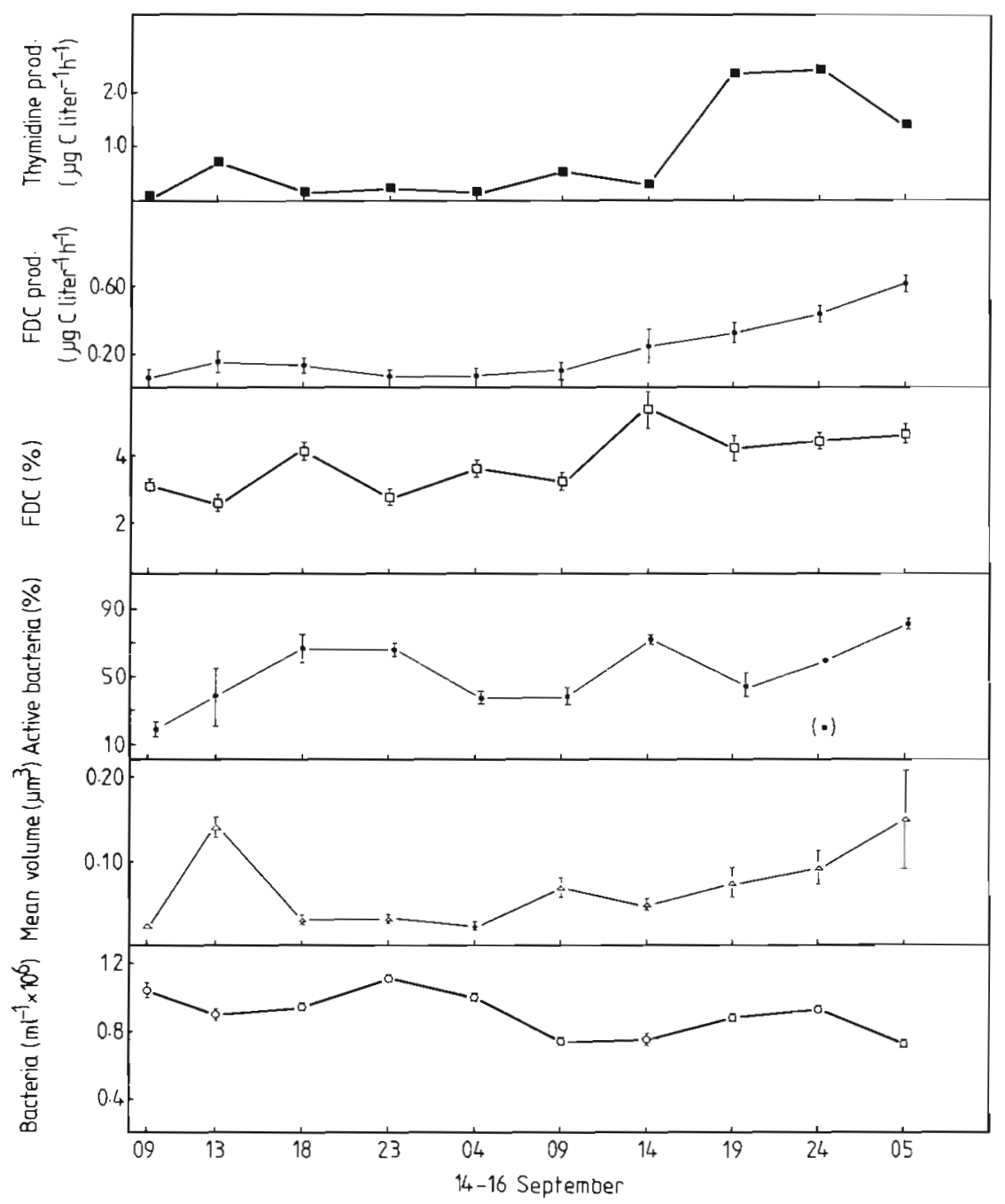

Fig. 2. Diel changes in bacterial numbers, mean volume, ${ }^{3} \mathrm{H}$-thymidine active bacteria (in \% of total bacteria), FDC $(\%)$, FDC calculated production and ${ }^{3} \mathrm{H}$-thymidine calculated production during 14 to 16 September in The Limfjord. Bars: total variation for 2 replicates. In brackets: grains difficult to see due to opaque emulsion layer
October than that observed during September and varied only between 17 and $35 \%$ There were smaller diel changes in October than in September.

The small changes in the bacterial numbers and the nearly constant temperature caused the FDC percentage and the mean volume alone to control changes in the FDC calculated bacterial secondary production. Large sudden changes in production were found, compared with results obtained from the thymidine incorporation technique. FDC production values were slightly higher than those obtained from thymidine incorporation into DNA.

The results calculated from thymidine incorporation using the literature-based 'conversion factor' were compared with those from the isotope dilution procedure and with results obtained from increases in bacterial biomass in $3 \mu \mathrm{m}$ filtrates. In 3 out of 5 experiments, linear isotope curves are obtained (Fig. $4 \mathrm{~A}, \mathrm{~B}, \mathrm{E}$ ), whereas Fig. $4 \mathrm{C}$ and $\mathrm{D}$ show a complex incorporation pattern. The straight lines in Fig. $4 \mathrm{C}$ and $\mathrm{D}$, were calculated from results including dilution up to $1 \mathrm{nmol}$. In all 5 experiments, the intercept on the abscissa gave more than $-0.25 \mathrm{nmol}$ (the amount of ${ }^{3} \mathrm{H}$-thymidine added), indicating a dilution of the isotope, probably by de novo synthesis. We assumed that additions of $0.25 \mathrm{nmol}$ per $80 \mathrm{ml}$ (corresponding to $3.1 \mathrm{nM}$ ) would reduce dilution of the ${ }^{3} \mathrm{H}$-thymidine from exogenous sources. Calculations of the production rates gave 1.3 to 3.0 times (mean 1.9) lower values with the isotope dilution procedure. Except for 15 September, production rates calculated from cell counts gave higher values than those obtained from the 2 thymidine procedures (Table 1).

Based on the assumption that all dividing cells were active, FDC (\%) and biomass were corrected according to the percent active bacteria, and new production rates were calculated from the September experiment (Table 2). In all experiments the generation time declined. Maximum decline occurred from 91 to $13 \mathrm{~h}$, average decline from 42 to $12 \mathrm{~h}$. Furthermore, in all 
Fig. 3. Diel changes in bacterial numbers, mean volume, ${ }^{3} \mathrm{H}$-thymidine active bacteria (in \% of total bacteria), FDC $(\%)$, FDC calculated production and ${ }^{3} \mathrm{H}$-thymidine calculated production during 12 to 14 October. After 0900 13 October, fresh seawater from the same station was filled into experimental bottles. Bars: total variation for 2 replicates

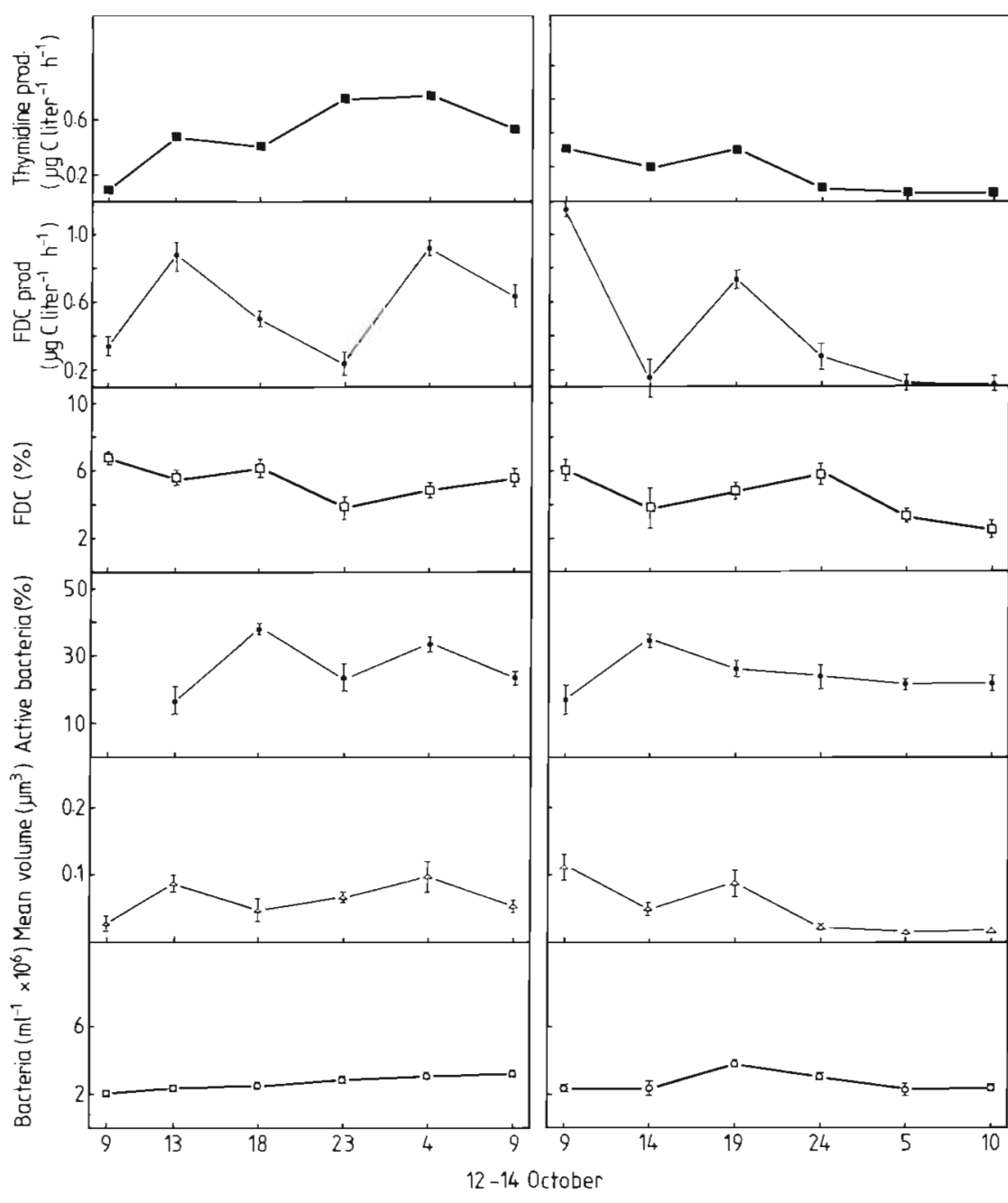

age activity determined from autoradiography, mean volume, FDC (\%) and - to some extent - the FDC calculated production from October.

Every morning an increase was found in the percentage of active bacteria determined from autoradiography; except for the morning of 14 October, increases were also seen in mean volume and in production. Such diel changes have previously been recorded from freshwater environments (Marcussen et al., 1984); they have been ascribed to phytoplankton extracellular release of organic carbon (Iturriaga, 1981; Riemann et al, 1982). However, other diel rhythms have also been found, supporting the idea that diel changes in bacterial production are controlled by a variety of events in natural environments (Riemann and Søndergaard, 1984).

Bacterial production estimated from thymidine procedure and FDC gave values of similar magnitude. Generally, production estimates made from FDC were lower than those made from thymidine incorporation in the September experiments, and somewhat higher during October. Despite these differences, the diel 

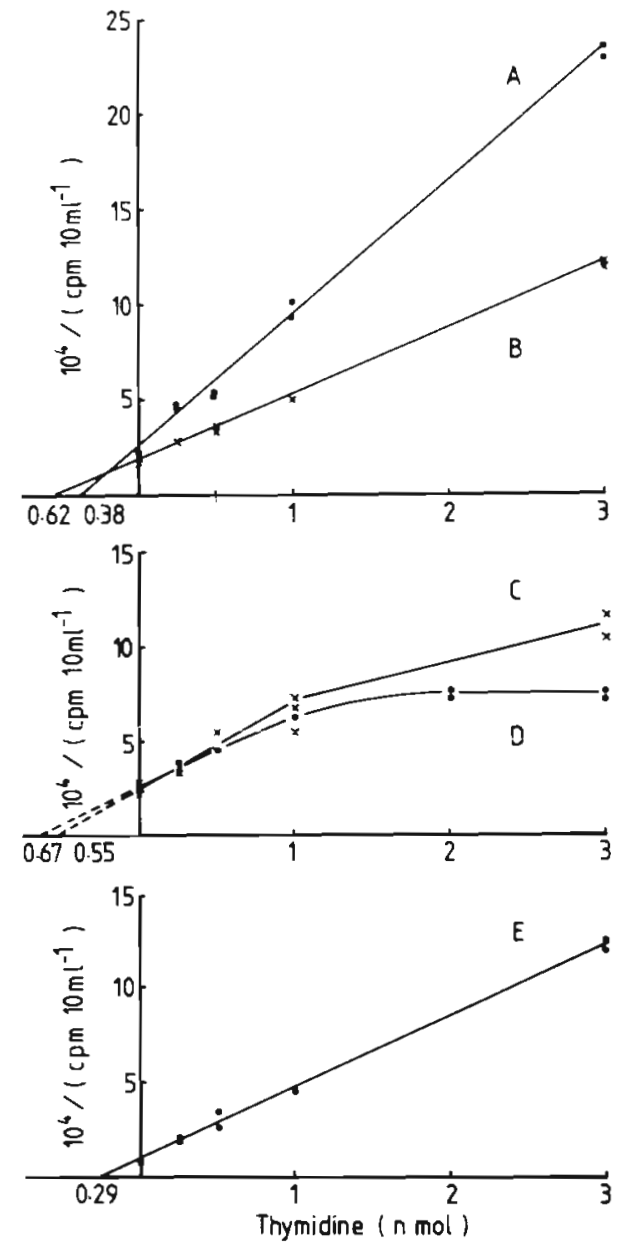

Fig. 4. Plots of the reciprocal of ${ }^{3} \mathrm{H}$-thymidine incorporated into DNA versus total amount of unlabeled thymidine added per $80 \mathrm{ml}$ samples from 5 experiments in The Limfjord. (A) 13 October 1300, (B) 13 October 1800, (C) 14 October 1400, (D) 14 October 1900, (E) 15 September 1900 . Additions of ${ }^{3} \mathrm{H}$-thymidine was $0.25 \mathrm{nmol}$ per $80 \mathrm{ml}$. Counts presented in cpm; counting efficiency was $40 \%$ for all samples

changes were similar, except at 2300 on 12 October, where an increase in the thymidine calculated production coincided with a decrease in the production estimated from FDC. Similar conclusions were made by Newell and Fallon (1982) and Riemann and Sønder- gaard (1984) who both reported high correlation coefficients from analysis of results of the 2 methods. In contrast to our results, Newell and Fallon (1982) found production rates in seawater measured with FDC to be 2 to 7 times higher than rates obtained with the ${ }^{3} \mathrm{H}$ thymidine method, and Riemann and Sondergaard (1984) reported up to 21 times higher values from FDC in lakes. The reason(s) for these discrepancies between our results and the previous findings is (are) still not clear; however, several critical points may explain these relations.

Important critical points in the FDC procedure include (1) difficulties in identifying dividing cells; (2) limited information about relations between FDC (\%), specific growth rate and temperature; (3) biomass of the bacterial assemblages, which is necessary to determine production rate in terms of carbon (this point is equally important for production estimates from thymidine incorporation); (4) FDC calculated production assumes that all cells are metabolically active.

Concerning the first point, there is still no alternative to epifluorescence microscopy. Scanning electron microscopy (SEM) is far too tedious to be used for estimating the percentage of dividing cells in routine analyses. However, SEM pictures clearly distinguish between dividing cells and cells out of the dividing stage. To evaluate FDC calculated production rates it is still necessary to present the actual FDC percentages, since the basis for this percentage includes a difficult discrimination between dividing and nondividing cells and is often based on rather few counts.

Concerning Point 2, it is still not possible to determine the specific growth rate accurately at temperatures above 15 or below $5{ }^{\circ} \mathrm{C}$ (Hagström et al., 1979). Larsson and Hagström (1982) calculated the specific growth rate from FDC (\%) obtained at temperatures above $15^{\circ} \mathrm{C}$ as if they had been obtained at $15^{\circ} \mathrm{C}$. Riemann (1983) plotted temperature versus specific growth rate $\left(\mathrm{h}^{-1}\right)$ for various FDC $(\%)$ values; points with the same FDC were connected through 5, 10 and $15^{\circ} \mathrm{C}$ and extrapolated to $20^{\circ} \mathrm{C}$ to cover many summer temperatures in coastal marine environments and in lakes. The published material about relations between

Table 1. Bacterial secondary production ( $\mu \mathrm{g} \mathrm{C} \mathrm{l}^{-1} \mathrm{~h}^{-1}$ ) measured in $3 \mu \mathrm{m}$ filtrates by means of (1) Fuhrman \& Azam (1982) thymidine approach; (2) isotope dilution procedure by Moriarty and Pollard (1981); (3) bacterial biomass changes. Bacterial biomass changes were measured from 1300 to 1800 on 13 October and from 1400 to 1900 on 14 October

\begin{tabular}{|ccccc|}
\hline Date & Time & Fuhrman and Azam & Moriarty and Pollard & Biomass changes \\
\hline $15 / 9$ & 1900 & 1.90 & 0.64 & 1.62 \\
$12 / 10$ & 1300 & 0.38 & 0.17 & 0.90 \\
$12 / 10$ & 1800 & 0.33 & 0.24 & 1.30 \\
$13 / 10$ & 1400 & 0.20 & 0.13 & 0.23 \\
$13 / 10$ & 1900 & 0.30 & & \\
\hline
\end{tabular}


FDC, temperature and specific growth rates is still rather limited and contains little information from freshwater.

Conceming Point 3, determination of the cell volume is under discussion. Our measured mean volumes ranged between 0.015 and $0.146 \mu \mathrm{m}^{3}$ (mean = $0.060 \mu \mathrm{m}^{3}$ ). Large discrepancies between published mean cell volumes from natural bacterial assemblages exist. Krambeck et al. (1981) estimated from SEM mean cell volumes as low as $0.017 \mu \mathrm{m}^{3}$ in eutrophic German lakes; they ascribed these low values to overestimations of the mean cell volume of small cells measured by epifluorescence techniques. Higher values are often obtained from lakes $\left(0.093\right.$ to $0.276 \mu \mathrm{m}^{3}$ : Pedrós-Alió and Brock, 1982; 0.083 to $0.279 \mu \mathrm{m}^{3}$ : Bell et al., 1983); also in marine environments mean cell volumes are often higher than those presented by Krambeck et al. (1981). For coastal waters, values often range between 0.05 and $0.09 \mu \mathrm{m}^{3}$ (Ferguson and Rublee, 1976; Fuhrman et al., 1980). According to Fuhrman (1981) epifluorescence techniques probably did not lead to large overestimations. His values for coastal waters off Southern California ranged between 0.081 and $0.145 \mu \mathrm{m}^{3}$ - somewhat higher than the values presented here.

Concerning Point 4, microautoradiographic analyses demonstrated that 20 to $80 \%$ of the bacterial assemblage was ${ }^{3} \mathrm{H}$-thymidine active. An important question is whether all dividing cells were metabolically active. A cell could theoretically cease to be active in the midst of division. This would overestimate the true FDC percentage and the calculated production rate. Although this phenomenon cannot be completely ignored, it seems not to be, from a general energetic point of view, a common phenomenon in most natural environments. Based on the assumption that all divid- ing cells were active, estimated bacterial biomass and FDC $(\%)$ were corrected, and new specific growth rates calculated. Generation time averaged $41 \mathrm{~h}$, using the normal procedure, but decreased to a mean of $12 \mathrm{~h}$, when calculated for active cells alone. Furthermore, this gave an increase in the production rate of up to $169 \%$ of the values calculated from the routine procedure. The calculated mean value increased by $28 \%$.

Significant diel changes occurred in the percentage of active bacteria. Similar diel changes in glucoseactive bacteria have previously been demonstrated, and variations comprised at most a factor of 3 with maximum values in the evening (Meyer-Reil et al., 1979). It is difficult to say whether the percentage of active cells we determined with tritiated thymidine would also apply to other compounds. Hoppe (1976) reported more labeled cells with an ${ }^{3} \mathrm{H}$-amino acid mixture and less glucose-labeled cells compared with those labeled from uptake of ${ }^{3} \mathrm{H}$-thymidine. Some of the observed changes in '\% activity' could be due to changes in average radioactivity per bacterium rather than changes in the distribution of radioactivity (Fuhrman and Azam, 1982). This may pertain to September vs October values, since both the '\% active' and average radioactivity per cell were somewhat lower in October

We evaluated the results obtained with the thymidine procedure in 2 ways: (1) by employing results obtained from increases in bacterial biomass in $3 \mu \mathrm{m}$ filtrates; (2) by comparing the values obtained from a literature-based 'conversion factor' to values partly based on an isotope dilution procedure (designed to correct for isotope dilution from exogenous and endogenous sources; Moriarty and Pollard, 1981). In the September experiment the routine thymidine procedure and the increase in biomass yielded similar

Table 2. Diel changes in active bacteria, FDC, specifjc growth rate, generation time, bacterial biomass, and bacterial production calculated by mean of the normal FDC procedure (N.), and calculated on the basis of percentage active bacteria (Corr.). FDC and biomass were corrected according to percentage active bacteria, assuming that all dividing cells belonged to the active biomass, and new generation times and production rates were calculated. All data from September

\begin{tabular}{|c|c|c|c|c|c|c|c|c|c|c|c|}
\hline \multirow[t]{2}{*}{ Time } & \multirow{2}{*}{$\begin{array}{c}\text { Active bacteria } \\
\text { (\% of total } \\
\text { bacteria })\end{array}$} & \multicolumn{2}{|c|}{$\begin{array}{l}\text { FDC } \\
(\%)\end{array}$} & \multicolumn{2}{|c|}{$\begin{array}{l}\text { Specific growth rate } \\
\qquad\left(\mathrm{h}^{-1}\right)\end{array}$} & \multicolumn{2}{|c|}{$\begin{array}{c}\text { Generation time } \\
\text { (h) }\end{array}$} & \multicolumn{2}{|c|}{$\begin{array}{l}\text { Bacterial biomass } \\
\qquad\left(\mu \mathrm{g} \subset 1^{-1}\right)\end{array}$} & \multicolumn{2}{|c|}{$\begin{array}{l}\text { Bacterial produc- } \\
\text { tion }\left(\mu g \mathrm{Cl}^{-1} \mathrm{~h}^{-1}\right)\end{array}$} \\
\hline & & $N$ & Corr. & $\mathrm{N}$ & Corr. & $N$ & Corr. & N. & Corr. & N. & Corr. \\
\hline 0900 & 18.9 & 3.1 & 16.4 & 0.0165 & $?$ & 61 & $?$ & 2.7 & 0.51 & 0.04 & $?$ \\
\hline 1300 & 37.4 & 2.6 & 7.0 & 0.0110 & 0.075 & 91 & 13 & 15.0 & 5.6 & 0.16 & 0.43 \\
\hline 1800 & 66.0 & 4.1 & 6.2 & 0.038 & 0.069 & 26 & 14 & 3.0 & 1.9 & 0.12 & 0.14 \\
\hline 2300 & 65.6 & 2.8 & 4.2 & 0.016 & 0.038 & 63 & 26 & 3.5 & 2.3 & 0.06 & 0.09 \\
\hline 0500 & 37.3 & 3.6 & 9.7 & 0.027 & 0.116 & 37 & 9 & 2.4 & 0.9 & 0.06 & 0.10 \\
\hline 0900 & 37.4 & 3.2 & 8.6 & 0.019 & 0.094 & 52 & 11 & 5.9 & 2.2 & 0.11 & 0.20 \\
\hline 1400 & 70.5 & 5.4 & 7.7 & 0.058 & 0.088 & 17 & 11 & 4.2 & 2.9 & 0.25 & 0.26 \\
\hline 1900 & 44.0 & 4.2 & 9.5 & 0.046 & 0.118 & 22 & 9 & 7.4 & 3.2 & 0.34 & 0.36 \\
\hline 2400 & 56.5 & 4.4 & 7.8 & 0.044 & 0.090 & 23 & 11 & 9.9 & 5.6 & 0.43 & 0.51 \\
\hline 0500 & 79.9 & 4.9 & 6.1 & 0.050 & 0.067 & 20 & 15 & 12.9 & 10.3 & 0.65 & 0.69 \\
\hline
\end{tabular}


estimates, whereas during the diel cycles in October, the production calculated from the increase in bacterial biomass was about 2 to 6 times higher than our routine thymidine procedure and about 4 to 10 times higher than the values from the isotope dilution procedure. The isotope dilution procedure yielded consistently lower values than either of the 2 methods, suggesting an underestimate of unlabeled pools. Kirchman et al. (1982) examined growth rates by means of thymidine incorporation into DNA and changes in bacterial biomass in natural assemblages diluted 10fold. They used the 2 methods together to estimate 'conversion factors' for calculating production from incorporation rates. They usually found 'conversion factors' within an order of magnitude of the $2.1 \times 10^{18}$ used here. Direct comparison between their results and ours is hampered by insufficient knowledge of whether (1) their model is generally applicable, and (2) the relation between incorporation and growth is the same for natural and their experimental conditions (dilution and extended incubations).

The limited material does not permit any sweeping generalisations. It is nevertheless interesting to note that during September with low numbers of bacteria and generally many active bacteria, the results from the thymidine approach and biomass changes (Table 1) produce nearly identical results. In contrast, the high numbers of bacteria in October contained a small proportion of active cells and large differences were obtained between the results. The results do not support the idea that fast growing cells dilute a significant proportion of the labeled thymidine incorporated into DNA via de novo synthesis, whereas slowly growing cells should have sufficient thymidine from exogenous sources (Moriarty and Pollard, 1982). On the contrary, our results tend to show the opposite pattern, still considering the limited amount of data.

We assumed that additions of $3.1 \mathrm{nM}^{3} \mathrm{H}$-thymidine were sufficient to overcome dilution from exogenous sources (Fuhrman and Azam, 1980; P. Kofoed et al., unpubl.). Moriarty (1984a) concluded from a number of seawater experiments (though only 1 experiment was presented) that isotope dilution did not occur in marine samples from pelagic systems, whereas large dilutions were observed from sediments. Unfortunately, no discrimination was made between dilution from exogenous or endogenous sources, so considering the concentrations of dissolved compounds in the sediments, most of the dilution might have come from exogenous sources. Interpretations of the isotope dilution curves are still debatable. Non-linear curves are often found, even when the concentration of cold thymidine is low (Moriarty 1984b; Riemann, unpubl.). Our present ideas on the isotope dilution procedure are that it is a very time-consuming analytical procedure, the results are often difficult to interpret because of non-linear isotope dilution curves and the statistical uncertainties on the intercept on the abscissa are large. Furthermore, if the rate limiting step in thymidine incorporation into DNA is uptake, then the isotope dilution procedure will not accurately estimate intracellular pool sizes. The fact that the Fuhrman and Azam (1982) approach, which assumes a 4.2-fold ultimate dilution of added thymidine, yielded production estimates closer to actual growth in $3 \mu \mathrm{m}$ filtrates than the isotope dilution procedure, suggests that actual pool sizes are underestimated by the dilution method.

In conclusion, only minor diel changes were found in cell numbers and production. However, appreciable changes were observed in percent active bacteria and in mean cell volume, especially during mornings. Bacterial secondary production, determined by means of FDC and ${ }^{3} \mathrm{H}$-thymidine incorporation into DNA gave results of the same magnitude, and diel changes were nearly the same. When biomass of the bacteria and FDC $(\%)$ were corrected for percent active bacteria, the average generation time for the bacterial assemblage decreased from $41 \mathrm{~h}$ to $12 \mathrm{~h}$ and production rates increased $28 \%$. These results demonstrate an interesting scenario for growth of natural bacterial assemblages. The subtle changes in biomass and a generation time of 12 to $41 \mathrm{~h}$ suggest a marked grazing pressure on the population. Such high grazing values by mainly choanoflagellates have recently been reported by Fenchel (1982). Furthermore, it suggests a tight coupling between new input of bacterial nutrients and the growth of bacterioplanktonic populations.

Acknowledgements. We thank W. Martinsen for technical assistance. This study was partly supported by the Danish Natural Science Research Council (J. nr. 11-3283 and 111816).

\section{LITERATURE CITED}

Bell, R. T., Ahlgren, G., Ahlgren, I. (1983). Estimating bacterioplankton production by measuring $\left({ }^{3} \mathrm{H}\right)$ thymidine incorporation in a eutrophic Swedish lake. Appl. environ. Microbiol. 45: 1709-1721

Christian, R. R., Hanson, R. B., Newell, S. Y (1982). Comparison of methods for measurement of bacterial growth rates in mixed batch cultures. Appl. environ. Microbiol. 43: $1160-1165$

Cuhel, R. L., Taylor, C. D., Jannasch, H. W. (1981). Assimilatory sulphur metabolism in marine microorganisms: sulphur metabolism, protein synthesis and growth of Pseudomonas haloclurans and Alteromonas luteo-violacens during unperturbated batch growth. Arch. Microbiol. 130: $8-13$

Fenchel, T. (1982). Ecology of heterotrophic microflagellates. IV. Quantitative occurrence and importance as bacterial consumers. Mar. Ecol. Prog. Ser. 9: 35-42 
Ferguson, R. L., Rublee, P. (1976). Contribution of bacteria to standing crop of coastal plankton. Limnol. Oceanogr 21: $141-145$

Fuhrman, J. A. (1981). Influence of method on the apparent size distribution of bacterioplankton cells: Epifluorescence microscopy compared to scanning electron microscopy. Mar Ecol. Prog. Ser 5: 103-106

Fuhrman, J. A., Ammerman, J. W., Azam, F. (1980). Bacterioplankton in the coastal euphotic zone: distribution, activity and possible relationships with phytoplankton. Mar Biol. 60: 201-207

Fuhrman, J. A., Azam, F. (1980). Bacterioplankton secondary production estimates for coastal waters of British Columbia, Antarctica, and California. Appl. environ. Microbiol. 39: 1085-1095

Fuhrman, J. A., Azam, F. (1982). Thymidine incorporation as a measure of heterotrophic bacterioplankton production in marine surface waters: evaluation and field results. Mar Biol. 66: 109-12ก

Hagström, A., Larsson, U., Hörstedt, P., Normark, S. (1979). Frequency of dividing cells, a new approach to the determination of bacterial growth rates in aquatic environments. Appl. environ. Microbiol. 37: 805-812

Hobbie, J. E., Daley, J., Jasper, S. (1977). Use of nuclepore filters for counting bacteria by fluorescence microscopy. Appl. environ. Microbiol. 33: 1225-1228

Hoppe, H.-G. (1976). Determination of properties of actively metabolizing bacteria in the sea, investigated by means of microautoradiography. Mar. Biol. 36: 291-302

Iturriaga, R. (1981). Phytoplankton photoassimilated extracellular products; heterotrophic utilization in marine environments. Kiel. Meeresforsch. Sonderh. 5: 318-324

Jordan, M. J., Likens, G. E. (1980). Measurements of planktonic bacterial production in an oligotrophic lake. Limnol. Oceanogr 25: 719-732

Karl, D. M. (1979). Measurement of microbial activity and growth in the ocean by rates of stable ribonucleic acid synthesis. Appl. environ. Microbiol. 42: 802-810

Karl, D. M. (1982). Selected nucleic acid precursors in studies of aquatic microbial ecology. Appl. environ. Microbiol. 44: 891-902

Kirchman, D., Ducklow, H., Mitchell, R. (1982). Estimates of bacterial growth from changes in uptake rates and biomass. Appl, environ. Microbiol. 44: 1296-1307

Krambeck, C., Krambeck, H.-J., Overbeck, J. (1981). Microcomputer-assisted biomass determination of plankton bacteria on scanning electron micrographs Appl. environ. Microbiol. 42: 142-149

Larsson, U., Hagström, \&. (1982). Fractionated phytoplankton primary production, exudate release and bacterial production in a Baltic eutrophication gradient. Mar Biol. 67 : $57-70$

Marcussen, B., Nielsen, P., Jeppesen, M. (1984). Diel changes in bacterial activity determined by means of microautoradiography. Verh. int. Verein. Limnol. (in press)

Meyer-Reil, L.-A. (1978). Autoradiography and epifluorescence microscopy combined for the determination of number and spectrum of actively metabolizing bacteria in natural waters. Appl. environ. Microbiol. 36: 506-512

Meyer-Rejl, L.-A., Bölter, M., Liebezeit, G., Schramm, W. (1979). Short-term variations in microbiological and chemical parameters. Mar. Ecol. Prog. Ser. 1: 1-6

Moriarty, D. J. W. (1984a). Measurements of bacterial growth rates in marine systems using nucleic acid precursors. In: Hobbie, J. E., Williams, P. J. LeB. (ed.) Heterotrophic activity in the sea. Plenum Press, New York (in press)

Moriarty, D. J. W (1984b). Measurement of bacterial growth rates in aquatic systems using rates of nucleic acid synthesis. In: Williams, P. J. LeB., Jannasch, H. (ed.) Advances in aquatic microbiology, Volume 3 (in press)

Moriarty, D. J. W., Pollard, P. C. (1981). DNA synthesis as a measure of bacterial productivity in seagrass sediments. Mar Ecol. Prog. Ser 5: 151-156

Moriarty, D. J. W., Pollard, P. C. (1982). Diel variations of bacterial productivity in seagrass (Zostera capricorni) beds measured by rate of thymidine incorporation into DNA. Mar Biol. 72: 165-173

Newell, S. Y., Fallon, R. D. (1982). Bacterial productivity in the water column and sediments of the Georgia (USA) coastal zone: estimates via direct counting and parallel measurements of thymidine incorporation. Microb. Ecol. 8: $33-46$

Pedrós-Alió, C., Brock, T D. (1982). Assessing biomass and production of bacteria in eutrophic Lake Mendota, Wisconsin. Appl. environ. Microbiol. 44: 203-218

Riemann, B. (1983). Biomass and production of phyto- and bacterioplankton in eutrophic Lake Tystrup, Denmark. Freshwat. Biol. 13: 389-398

Riemann, B., Fuhrman, J. A., Azam, F. (1982). Bacterial secondary production in freshwater measured by ${ }^{3} \mathrm{H}$-thymidine incorporation method. Microb. Ecol. 8: 101-114

Riemann, B., Sondergaard, M. (1984). Measurements of diel rates of bacterial secondary production in aquatic environments. Appl. environ. Microbiol. 47: 632-638

Watson, S. W., Novitsky, T J., Quinby, H. L., Valois, F. W (1977). Determination of bacterial number and biomass in the marine environment. Appl. environ. Microbiol. 33: $940-946$

This paper was submitted to the editor; it was accepted for printing on March 11, 1984 